\title{
Messing with the Sentinels-The Interaction of Staphylococcus aureus with Dendritic Cells
}

\author{
Murthy N. Darisipudi ${ }^{\mathbb{D}}$, Maria Nordengrün ${ }^{(\mathbb{D}}$, Barbara M. Bröker ${ }^{(\mathbb{D})}$ and Vincent Péton * \\ Department of Immunology, University Medicine Greifswald, Ferdinand-Sauerbruch-Straße DZ7, \\ D-17475 Greifswald, Germany; venkata.darisipudi@uni-greifswald.de (M.N.D.); \\ maria.nordengruen@uni-greifswald.de (M.N.); broeker@uni-greifswald.de (B.M.B.) \\ * Correspondence: vincent.peton@uni-greifswald.de; Tel.: +49-3834-865460
}

Received: 6 July 2018; Accepted: 14 August 2018; Published: 15 August 2018

\begin{abstract}
Staphylococcus aureus (S. aureus) is a dangerous pathogen as well as a frequent colonizer, threatening human health worldwide. Protection against $S$. aureus infection is challenging, as the bacteria have sophisticated strategies to escape the host immune response. To maintain equilibrium with $S$. aureus, both innate and adaptive immune effector mechanisms are required. Dendritic cells (DCs) are critical players at the interface between the two arms of the immune system, indispensable for inducing specific $\mathrm{T}$ cell responses. In this review, we highlight the importance of DCs in mounting innate as well as adaptive immune responses against $S$. aureus with emphasis on their role in $S$. aureus-induced respiratory diseases. We also review what is known about mechanisms that S. aureus has adopted to evade DCs or manipulate these cells to its advantage.
\end{abstract}

Keywords: S. aureus; dendritic cells; innate immunity; adaptive immunity; immune evasion; infection

\section{Introduction}

Staphylococcus aureus (S. aureus) can act as a commensal bacterium in humans, where it frequently colonizes the airways, skin and gut. In most cases, the host can maintain equilibrium with the bacteria over long time periods. However, given the opportunity, S. aureus can cause a broad range of infections, ranging from mild, self-limiting skin and soft tissue infections to life-threatening diseases [1]. In the airways, $S$. aureus can cause pneumonia, and colonization with the bacteria is associated with allergic airway inflammation, especially with chronic rhinosinusitis with polyps and asthma [2]. Similarly, S. aureus is frequently found on inflamed skin of patients with atopic dermatitis (AD) [3].

Although S. aureus mainly has an extracellular lifestyle, the microorganism is also able to invade phagocytes as well as epithelial and endothelial cells and persist intracellularly [4]. To control the bacteria and the infected cells, the host immune system uses every level of its defense mechanisms [1]. Innate and adaptive immunity are involved, and both humoral and cellular effector mechanisms are required to keep the microorganism in check. Being at the interface between innate and adaptive immune responses, dendritic cells (DCs) must be central to the immune protection against S. aureus [5].

Recognition of $S$. aureus by professional phagocytes, such as monocytes (MOs), macrophages $(\mathrm{M} \varphi s)$ and DCs, induces the release of cytokines and chemokines, and the latter recruit neutrophils to the site of infection. Neutrophils are essential for killing the bacteria, either by phagocytosis or by NETosis. Phagocytosis is a process of engulfing and digestion of bacteria inside the cell, whereas NETosis involves trapping of bacteria in net-like structures, called neutrophil extracellular traps (NETs), which consist of DNA and histones as well as the content of neutrophil granules, such as anti-microbial peptides (AMPs) and elastase [1]. As a counter measure, S. aureus secretes many proteins that interfere with both the recognition by phagocytes and their chemotaxis to the infection site [6]. The microorganism is further capable of destroying NETs by nuclease production [7]. 
The humoral arm of the innate immune system, the complement cascade, is also indispensable in the defense against $S$. aureus. Complement factors or their fragments can promote opsonization to facilitate microbial clearance $(\mathrm{C} 3 \mathrm{~b})$ and drive inflammation (C3a and $\mathrm{C} 5 \mathrm{a})$. These functions are mediated by specific complement receptors (CRs) on host cells. Moreover, complement can kill many bacterial species directly by forming pores in their membranes, the membrane attack complexes (MACs). In return, S. aureus interferes with complement function at many levels. A capsule and a thick peptidoglycan layer protect its membrane from MAC (reviewed in $[1,8]$ ). By inhibiting the central hub of the complement cascade, the $\mathrm{C} 3$ convertase, $\mathrm{S}$. aureus reduces the production of $\mathrm{C} 3 \mathrm{~b}, \mathrm{C} 3 \mathrm{a}$ and $\mathrm{C} 5 \mathrm{a}$, interfering with both opsonization and inflammation [1,9]. These findings are in line with the previously observed role of C3 in controlling S. aureus bacteremia [10]. In addition, in a mouse model of $S$. aureus-septic arthritis, deficiency of $\mathrm{C} 3$ diminishes opsonization and phagocytosis of S. aureus and thereby impairs host defense [11].

Considering adaptive immunity, there is compelling evidence that antibodies contribute to clinical protection from S. aureus infection. Most human adults have a broad spectrum of S. aureus- specific antibodies in their body fluids with large inter-individual variation in terms of antibody titers and the spectrum of $S$. aureus antigens that are recognized $[12,13]$. High titers of specific antibodies are associated with a reduced risk of $S$. aureus infection and/or a less severe disease course [14]. Conversely, hyperimmunoglobulin E syndrome (HIES) patients are highly susceptible to recurrent S. aureus infection. In the majority of cases the disease is caused by heterozygous missense mutations and short deletions in signal transducer and activator of transcription 3 (STAT3) leading to an impairment of T cell development, in particular of Th17 cells. Recently it was shown that HIES patients also have very low anti-S. aureus antibody titers, although total serum IgG levels are in the normal range. Presumably, this is due to their impaired T cell response, which we discuss in detail below. Immunoglobulin (Ig)G replacement therapy significantly ameliorates $S$. aureus control, with concomitant antibiotic treatment, which makes a strong case of a protective role of antibodies $[15,16]$.

Binding of IgG antibody to Fc receptor on phagocytes can opsonize the bacteria, whereas binding of IgG and IgM to bacteria triggers the complement cascade. Moreover, antibodies can neutralize $S$. aureus toxins and other virulence factors [12].

Recent studies have highlighted the importance of $\mathrm{T}$ cell-mediated immune response in S. aureus clearance. In a mouse model of persistent $S$. aureus infection, deficiency of $T$ cells increased the susceptibility to S. aureus [17]. In addition, in murine models of nasal colonization and cutaneous infection, production of interleukin (IL)-17A by Th17 cells is required for bacterial clearance by promoting neutrophil influx to the site of pathogen invasion [18]. Furthermore, as discussed before, HIES patients with a defect in the STAT3 signaling pathway, display impaired Th17 differentiation and are highly susceptible to recurrent severe infections with S. aureus [19].

It is well known that most B cells require help by $\mathrm{T}$ cells to generate high affinity antibodies, such that the observation of a broad S. aureus-specific antibody repertoire indicates the existence of numerous $S$. aureus-specific T cells. Several recent studies have provided evidence for robust CD4+ and CD8+ T cell memory of staphylococcal antigens in humans [20-22].

There is limited knowledge about the mechanisms by which $S$. aureus activates the T cells and directs their differentiation into effector and memory $\mathrm{T}$ cell subpopulations, but $\mathrm{DCs}$ are bound to be critically involved. DCs have a central role as antigen-presenting cells (APCs) for T cells, and they have a decisive influence on the quality of the adaptive immune reaction.

In this article, we review different aspects of DC physiology and how these cells interact with S. aureus during colonization and infection. We also address the countermeasures $S$. aureus uses to divert and disturb the immune response triggered by recognition of the bacteria by DCs, including the induction of allergic inflammation (illustrated in Figure 1). We place emphasis on the airway environment, because multifaceted interactions between $S$. aureus and its host take place at this site: colonization, infection and allergy. 


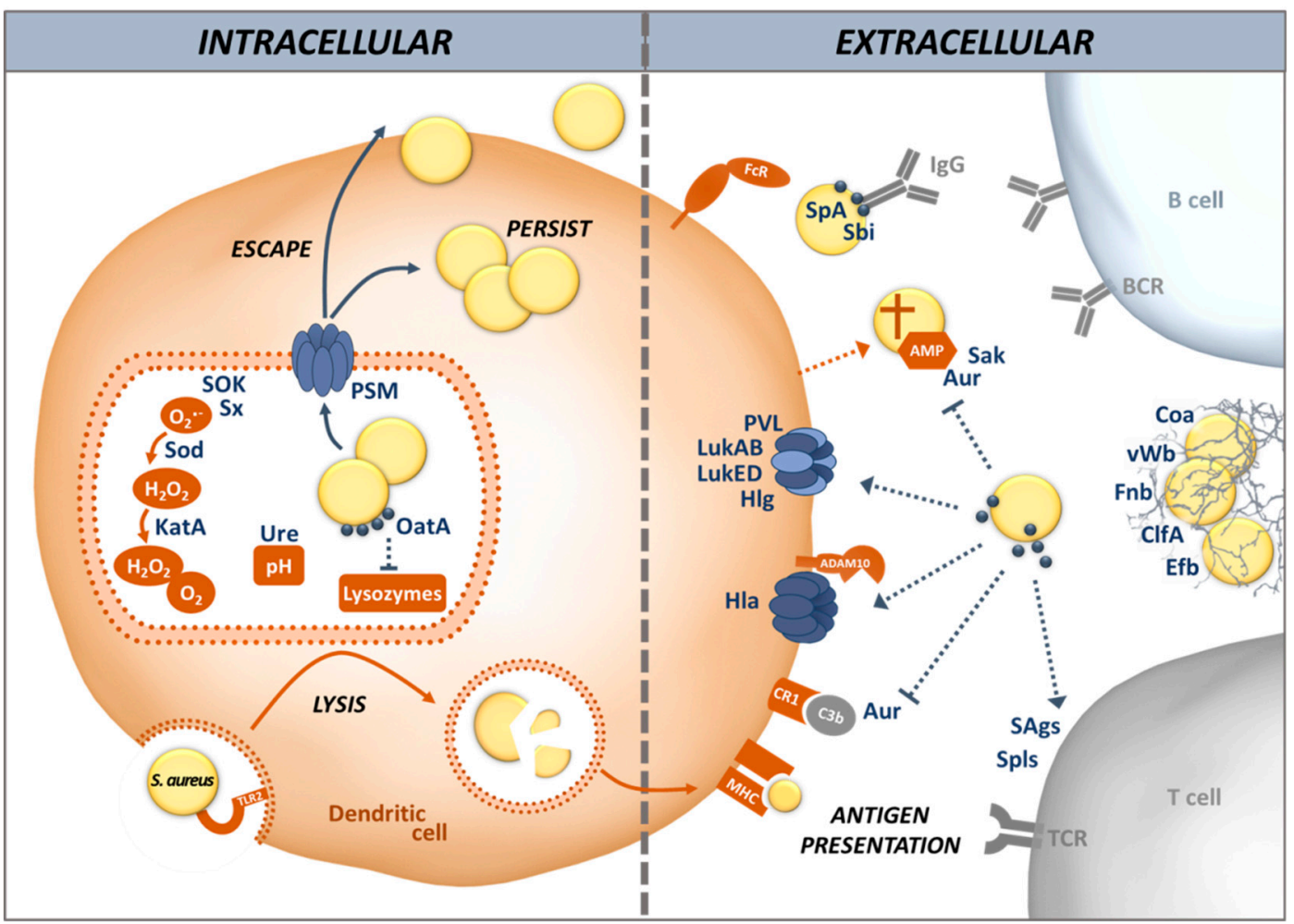

Figure 1. S. aureus' interaction with a dendritic cell during an infection. As antigen-presenting cells DCs are able to take up S. aureus, lyse the bacteria and present bacterial peptides on MHC class II to initiate a specific T cell response. However, S. aureus displays a broad range of mechanisms to avoid opsonization, phagocytosis and proteolytic degradation by DCs. In the extracellular space, S. aureus avoids opsonization by blocking antibody and complement function. SpA captures antibodies via their Fc region, thereby preventing recognition by Fc receptors. Aur cleaves complement factor $\mathrm{C} 3$ into non-functional C $3 b$. ClfA, Efb and FnbAB bind to fibrinogen and fibronectin, respectively, facilitating the formation of a mesh that protects $S$. aureus from phagocytosis. The coagulases $\mathrm{Coa}$ and $\mathrm{vWb}$ potentiate this process by mediating the conversion of fibrinogen into fibrin. After engulfment by phagosomes, S. aureus can increase the local $\mathrm{pH}$ by producing Ure, preventing efficient lysis. OatA acetylates the peptidoglycan cell wall, rendering S. aureus resistant to lysozymes. The Sx and SOK have antioxidant properties, protecting $S$. aureus from membrane damage. In addition, S. aureus SodA, SodM and KatA can act in cascade to detoxify ROS. PSMs enable S. aureus to escape from the phagosomes, thus invading the cytoplasm and possibly killing the host cell, which releases $S$. aureus into the extracellular space. AMPs secreted by DCs can be degraded by Aur and Sak, protecting S. aureus from being killed. Furthermore, S. aureus produces several pore-forming toxins, among them Hla and the bi-component toxins LukAB, LukED, PVL and Hlg, that can directly kill DCs. Finally, S. aureus SAgs and Spls are able to modulate the balance of the initiated T cell response towards a more favorable Th2 profile. Brown: DC factors; blue: S. aureus factors. Abbreviations: ADAM10: A disintegrin and metalloproteinase domain-containing protein 10; AMP: Anti-microbial peptides; Aur: Aureolysin; BCR: B cell receptor; DCs: Dendritic cells; C3: Complement factor 3; Clf: Clumping factor; Coa: Coagulase; CR1: Complement receptor 1; Efb: Extracellular fibrinogen binding protein; Hla: Alpha-hemolysin; Hlg: Gamma-hemolysin; Fc: Fragment crystallizable; Fnb: Fibrinonectin-binding protein; Kat: Catalase; Luk: Leukocidin; MHC: Major histocompatibility complex; OatA: O-acetyltransferase A; PSM: Phenol-soluble modulin; PVL: Panton-Valentine leucocidin (PVL); ROS: Reactive oxygen species; SAgs: Superantigens; Sod: Superoxide dismutase; SOK: Surface factor promoting resistance to oxidative killing; SpA: S. aureus protein A; Spls: Serine protease-like proteins; Sx: Staphyloxanthin; TCR: T cell receptor; TLR2: Toll-like receptor 2; vWb: von Willebrand factor-binding protein; Ure: Urease. 


\section{Dendritic Cells}

DCs were first described by Paul Langerhans in 1868 [23] as "branched skin cells resembling neurons", hence the term of Langerhans cells for skin DCs. Steinmann and Cohn proposed the term "dendritic cells" in 1973 and characterized their "tree-like" morphology (Greek, dendron) and tissue distribution in mice [24].

DCs are highly specialized phagocytic cells. Their main function is antigen presentation to $\mathrm{T}$ cells, and they have the unique ability to initiate and regulate both innate and adaptive immune responses against various antigens [25]. DCs originate in the bone marrow and travel through the blood into the tissues throughout the body, including the skin, mucosal tissues and lymphoid organs [26-28]. As sentinel cells in the tissues, DCs continuously take up antigen, sampling their microenvironment. Upon recognition of pathogen-associated and danger-associated signals, they initiate a response of the adaptive immune system. The DCs stop taking up additional antigen and migrate from the local tissue to secondary lymphoid organs, where they differentiate into mature DCs. The latter express high levels of major histocompatibility complex (MHC) class I and II, adhesins and costimulatory molecules, and can thus act as professional APCs for T cells [29]. They efficiently activate naïve antigen-specific T cells and strongly influence their differentiation into different subsets such as Th1, Th2, Th17 or Tregs.

In addition to their crucial role at the interface between innate and adaptive immune system as professional APCs, DCs contribute to the clearance of the opportunistic pathogen S. aureus. Although their ability to directly kill $S$. aureus is limited, they play a major role in the initiation and regulation of the immune response at the infection site $[4,5,26,30]$. By producing cytokines, DCs are essential for the recruitment of other effector cells specialized in killing bacteria, e.g., neutrophils [5,31]. In addition, IL-27 from APCs reduces the $\mathrm{pH}$ of phagolysosomes which boosts the ability of DCs to kill intracellular bacteria [32]. Moreover, activated platelets can stimulate DCs via CD40L production and improve their maturation, increasing cytokine secretion as well as antigen presentation in case of S. aureus infection [33].

DCs are generated during hematopoiesis from precursors of lymphoid or myeloid origin, which is an antigen-independent process. The progenitors in the bone marrow, called macrophage- and DC precursors (MDP), give rise to DCs and $\mathrm{M} \varphi \mathrm{s}$ [34]. In recent years, awareness of the existence of several types of DCs has grown. Depending on their phenotype, function and tissue distribution [35,36], they are broadly classified into two major groups: conventional or classical DCs (cDCs) $[24,37,38]$ and non-conventional DCs [39], with each group comprising more than one distinct subpopulation.

cDCs originate from pre-cDCs under the influence of granulocyte-macrophage colony stimulating factor (GM-CSF) and IL-4. This type of bone marrow-derived DCs has been extensively studied in in vitro experiments, and they are the most valuable source of knowledge about human and murine DCs. In vivo, the precursors of DCs exit the bone marrow and migrate through the blood into lymphoid tissues, bone marrow, spleen and lymph nodes, where they differentiate into cDCs characterized by the integrin CD11c [40]. Since $\mathrm{M} \varphi$ s also express CD11c, additional markers are required. Tyrosine kinase receptor "fms-like tyrosine kinase 3" (Flt3 or CD135) is an excellent marker that distinguishes $\mathrm{cDC}$ from $\mathrm{M} \varphi \mathrm{s}$. cDCs are further divided into subgroups based on their tissue localization and cell surface markers. In mice, lymphoid cDCs cells express CD8 $\alpha$ and CD4 (referred to here as CDC1), which constitute about 20-40\% of total spleen and LN cDCs, while human cDCs cells express CD370 (Clec9A) and the chemokine receptor XCR1 [41,42]. cDCs in non-lymphoid tissues are either CD103+ $\mathrm{CD} 11 \mathrm{~b}-$ or $\mathrm{CD} 103-\mathrm{CD} 11 \mathrm{~b}+$ (referred to here as CDC2) and lack the marker CD8. However, both $\mathrm{CD} 8+\mathrm{cDCs}$ and CD11b + cDCs proliferate in response to Flt3 (reviewed in [42]). Human and murine CDC1 cells that reside in the barrier organs such as the skin, skin-draining lymph nodes and murine Peyer's patches, express the integrin CD103 [43].

cDCs are key players in the polarization of the T cell response. cDCs1 secrete Th1 polarizing cytokine IL-12p70, but are also capable of producing immune regulatory cytokines such as transforming growth factor beta (TGF- $\beta$ ) and IL-10, both important in immune tolerance [44]. cDC2 induce the Th2 immune response to helminth infections, whereas fungal pathogens induce the Th17 immune response. 
In humans, cDC2 cells are characterized by expression of CD103, FcR1A and the alpha-chain of the high affinity receptor for IgE [45]. Compared to $\mathrm{CDC} 1, \mathrm{CDC} 2$ in mouse and human are less capable of presenting antigens via MHC class II [46].

Plasmacytoid DCs (pDCs) were first reported in 1958 by Lennert et al., and named by their appearance, which resemble plasma cells [39]. Precursors of pDCs express low levels of the GM-CSF but high amounts of the IL-3 receptor, and they differentiate into pDCs in response to IL-3 [47,48]. Human pDCs are characterized by their intermediate expression of CD11c, low levels of MHC class II and high density of CD123, but lack of CD11b [49,50]. In mice, pDCs exhibit surface markers that are shared with other cell types, e.g., B220 and Ly6C [51,52]. pDCs are found circulating in the blood and in peripheral organs such as bone marrow, spleen, thymus, lymph nodes, and the liver. They are known to play an important role in the production of type I interferons (IFN)- $\alpha / \beta$ by virtue of their capacity to sense viral nucleic acids [53,54].

\section{Recognition and Uptake of S. aureus by DCs}

DCs can efficiently recognize a wide range of invading microorganisms. The pattern recognition receptors (PRRs), which are expressed on their surface, can sense pathogen-associated molecular patterns (PAMPs) or damage associated molecular patterns (DAMPs). Among all PRRs, the Toll-like receptors (TLRs) are particularly well studied and characterized. They play a key role in inducing both direct and indirect DC maturation. To date, 10 human TLRs (TLR1-10) and 12 murine TLRs (TLR1-9, TLR11-13) have been identified. TLR1, 2, 4-6 and 11 are expressed at the cell surface while TLR3 and 7-9 are located intracellularly in the endosomal compartments [55].

TLR2 is the main receptor involved in S. aureus recognition, through the detection of lipoproteins, wall teichoic and lipoteichoic acid, as well as peptidoglycan [56,57]. In association with TLR1 or TLR6, TLR2 is able to sense diacyl or triacyl lipopeptides or lipoproteins [58]. Counteracting this, staphylococcal superantigen-like proteins (SSL) 3 and 4 inhibit TLR2 through interfering with both lipopeptide binding and TLR dimerization [59]. In a murine model of infection, S. aureus has been shown to evade TLR2 activation by secreting SSL3, indicating that TLR2 inhibition is important for staphylococcal pathogenesis [60]. The production of phenol soluble modulins (PSMs) increases the release of lipoproteins from the surface of $S$. aureus, whereas $S$. aureus strains producing low amounts of PSMs are less detected by TLR2 [56]. In AD, a chronic allergic inflammatory disease of the skin, DCs are less responsive to TLR2 stimulation, which could blunt their anti-S. aureus activity [61]. Colonization of lesional skin by S. aureus occurs in $90 \%$ of AD patients aggravating the inflammation and sometimes leading to severe invasive infections such as endocarditis or bacteremia [62]. TLR8 in MOs, M $\varphi s$ and DCs senses $S$. aureus RNA, a vita-PAMP enabling the assessment of microbial viability $[63,64]$. TLR9 binds $S$. aureus CPG-DNA and induces type I IFN signaling [65]. In osteoblasts, TLR9 also improves the killing of $S$. aureus by increasing the production of reactive oxygen species (ROS) [66]. Persistent $S$. aureus carriers have a higher expression of TLR9 that is dependent on the carrier's TLR9 haplotype, sex and hormone status, which could explain why women are more susceptible to $S$. aureus septicemia than men $[67,68]$.

To escape PRR-triggered phagocytosis and avoid the reaction of host cells to danger signals, S. aureus produces many proteins enabling it to invade different cell types, including non-phagocytic cells, via a zipper-type mechanism $[69,70]$. This is mediated by adhesins, known as microbial surface components, which recognize adhesive matrix molecules (MSCRAMMs) [71]. MSCRAMMs, including the fibronectin binding proteins (Fnb) A and B, are covalently linked to the peptidoglycan cell wall and involved in adhesion of S. aureus to the host cell matrix (Figure 1). S. aureus Fnb A and B bind to the host cell integrin $\alpha_{5} \beta_{1}$ via a fibronectin bridge. Other MSCRAMMs such as clumping factor (Clf) A and B are also involved in the attachment of S. aureus to host cells. Protein A (SpA), in contrast, interacts directly with host cell receptors [72]. These mechanisms stimulate actin rearrangement in the host cell and S. aureus is internalized without triggering TLRs [70,73,74]. 
Other adhesins, known as secretable expanded repertoire adhesive molecule (SERAMs), are released by S. aureus and re-attach to the bacterial surface non-covalently. The autolysin (Alt) family of proteins, AltA and Aaa, mediate adherence of $S$. aureus to host components such as fibronectin, gelatin and heparin, facilitating colonization and infection [75]. Among the SERAMs, the extracellular adherence protein (Eap) and extracellular matrix and plasma binding protein (Emp) have been shown to bind to host extracellular matrix components and plasma proteins, such as fibrinogen, fibronection, vitronectin, collagen, as well as to the endothelial cell adhesion receptor ICAM-1 [76,77]. Other SERAMs exploit the host's coagulation system. Staphylocoagulase (Coa) and von Willebrand factor-binding protein $(\mathrm{vWbp})$ activate prothrombin by inducing a conformational change to form a complex that cleaves fibrinogen into fibrin. ClfA then binds to the resulting fibrin cables to form a mesh, thus protecting $S$. aureus from phagocytosis and inducing abscesses. In this way, S. aureus can aggregate and shield themselves from phagocytes in a tight network thanks to bacterial and host proteins [78].

Opsonization is an efficient way to help phagocytes, including DCs, to take up bacteria and target them for killing. Igs and complement components are the main opsonins in the body fluids. Phagocytes possess specific receptors for IgG as well as the main complement opsonin C3b. DCs express Fc $\gamma$ receptors on their surface that bind to $\operatorname{IgG}$, helping the DC to immobilize their target for phagocytosis [79]. However, S. aureus possesses a broad range of factors that can prevent opsonization, either by hiding the targets of the opsonins or by using decoys. Many S. aureus strains are encapsulated by sugar polymers that cover most of the immunogenic surface-exposed proteins [80]. The two main serotypes are capsular polysaccharide (CP) 5 and CP8, which represent about $75 \%$ of all clinical isolates. Although strains producing a capsule are more resistant to phagocytosis, this resistance is overcome when specific Igs bind to the capsule polymers [81]. Interestingly USA300, one of the main CA-MRSA clones, does not display any capsule, demonstrating that capsule targeting vaccines cannot cover the whole diversity of $S$. aureus clones. Moreover, all S. aureus clinical isolates produce $\mathrm{SpA}$, a major virulence factor, which binds with high affinity to the Fc-portion of Igs, mostly IgG, rendering them unable to bind to the bacterial surface in the correct orientation and thus preventing opsonization [82]. SpA can also act as a B cell superantigen, since it binds to B cell receptors which use the $\mathrm{V}_{\mathrm{H}} \mathrm{III}$ element, inducing apoptotic cell death. This can result in the complete deletion of the respective $\mathrm{B}$ cell clones [83].

DCs possess CR3 (CD11b/CD18) and CR4 (CD11c/CD18), such that coating of S. aureus with $\mathrm{C} 3 \mathrm{~b}$ facilitates phagocytosis [84]. However, S. aureus is adept in complement evasion. Many secreted proteins such as SpA, aureolysin (Aur), staphylokinase (Sak), extracellular fibrinogen-binding protein $(\mathrm{Efb})$, and staphylococcal complement inhibitor (SCIN) interact with components of the complement pathways, preventing this system from fulfilling its purpose in opsonization and killing of pathogens (Reviewed in [1,85]). For instance, Aur cleaves C3 to produce a non-functional C3b fragment, hence preventing a normal activation of the complement and its opsonizing effects [86]. Furthermore, Sak and Aur can also bind and degrade secreted antimicrobial peptides such as $\alpha$-defensins and LL-37, before these can cause pores in the bacterial membrane [87-89].

To kill before being killed is another strategy of $S$. aureus, which is effective even before the bacteria are taken up by the host cells. S. aureus produces bi-component pore-forming toxins called leukocidins (Luks) which play a pivotal role in killing host immune cells, including DCs. The target structures of these toxins on host cells have been identified over the past few years (reviewed in [90]). LukED targets the C-C chemokine receptor (CCR) 5 as well as the C-X-C motif chemokine receptor (CXCR) 1 and CXCR2, to kill DCs, T cells and M $\varphi s$ [91,92]. LukAB specifically binds to the CD11b I domain in human but not murine polymorphonuclear cells (PMNs) and allows S. aureus to either kill its host cell or escape from phagosomes [93]. Since some subpopulations of DCs express CD11b, as part of the CR3, they can be targeted by LukAB [42,93-95]. LukMF' is mostly found in S. aureus isolates from ruminants and is associated with bovine infections. It targets CCR2 and CCR 5 on bovine and CCR1 on both human and bovine neutrophils and induces cell death [96]. These CCRs are also found on human DCs, which make them vulnerable targets [97]. The specificity of gamma-hemolysin 
(Hlg) depends on the subunits forming the toxin. The heterodimer HlgAB has a hemolytic function by binding to the Duffy Antigen Receptor for Chemokine (DARC) on erythrocytes and can also target CXCR1, CXCR2 and CCR2 on DCs [97-99]. HlgCB binds to the same targets as Panton-Valentine leukocidin (LukSF-PV, also known as PVL), C5aR and C5L2 [98]. Moreover, some toxin subunits can cross-interact with others and form hybrid toxins, which might increase the number of targets on the surface of host cells. For instance, HlgB can compete with LukS-PV and LukD to interact with LukF-PV [100,101].

\section{S. aureus Evades Killing by DCs as well as Antigen Processing and Presentation}

After internalization by phagocytosis, S. aureus is exposed to bactericidal effector mechanisms in DCs. Phagosomes mature and fuse with lysosomes containing hydrolases. In the phagolysosomes, S. aureus is also subjected to oxidative conditions rich in ROS and reactive nitrogen species (RNS). NADPH oxidase (NOX2) consumes oxygen to produce superoxide radical anions $\left(\mathrm{O}_{2}{ }^{\bullet-}\right)$ and hydrogen peroxide $\left(\mathrm{H}_{2} \mathrm{O}_{2}\right)$. Oxidation modulates the activities of different groups of proteases and thus reduces proteolysis within phagosomes of DCs [102]. In addition to this oxidative stress, S. aureus is also submitted to acidic $\mathrm{pH}$. Acidification of phagosomes in DCs is reduced compared to $\mathrm{M} \varphi$ s or neutrophils because the responsible enzyme, the V-ATPase, is incompletely assembled in immature DCs [30]. Proteases are therefore less active such that proteins are only partially degraded [103]. While reducing the ability of DC to truly clear the bacteria, incomplete protein degradation permits DCs to expose a higher diversity of peptides on MHC class II to efficiently prime T cell responses. Depending on the signals from their microenvironment, most importantly the nature of the infectious agent, DCs release various cytokines that direct the differentiation of naive $\mathrm{CD} 4+\mathrm{T}$ cells into different effector and memory T cell subsets.

However, in many cases $S$. aureus manages to survive within eukaryotic host cells, including professional and non-professional phagocytes [104]. Acidification of the phagolysosome is counteracted by secretion of urease, which increases the $\mathrm{pH}$ by hydrolyzing urea into ammonia [105]. S. aureus is also highly resistant to oxidative stress, because staphyloxanthin (Sx), the main pigment of S. aureus, works as an antioxidant and prevents membrane peroxidation [106]. SOK (surface factor promoting resistance to oxidative killing) displays similar properties and is considered a virulence factor in endocarditis [107]. SodA, SodM and KatA act in cascade to detoxify $\mathrm{O}_{2}{ }^{-}$into $\mathrm{H}_{2} \mathrm{O}_{2}$ and then into $\mathrm{H}_{2} \mathrm{O}+\mathrm{O}_{2}[108,109]$. A recently discovered molecule, the staphylococcal peroxidase inhibitor (SPIN), inhibits myeloperoxidase (MPO) in neutrophils and protects $S$. aureus from oxidative stress during phagocytosis [110]. DCs lack MPO, but they are influenced by the neutrophil-derived enzyme, which inhibits antigen uptake and processing by DCs, as well as their migration to lymph nodes and, as a consequence, T cell priming [111,112]. MPO-inhibition by SPIN could, therefore, enhance S. aureus survival in neutrophils with a trade-off: promoting the induction of an adaptive immune response by DCs.

Modification of the bacterial cell wall is another way to avoid degradation. The $O$-acetyltransferase A (OatA) adds an acetyl group to $\mathrm{N}$-acetylmuramic acid in the peptidoglycan, rendering S. aureus resistant to the lysozyme produced in the phagosome [113]. This may be one reason why lipoproteins that are embedded in the cell wall do not elicit a strong adaptive immune response [114].

Moreover, S. aureus has means to destroy the phago(lyso)some membrane and escape into the cytoplasm. Upon internalization by professional phagocytes, the bacteria produce phenol-soluble modulins (PSMs), similar to the delta hemolysin, which can form membrane pores. In DCs, PSMs help $S$. aureus to escape from the phagosome, invade the cytoplasm and possibly kill the host cell [115-117]. PSMs are under the positive control of the agr system, a global regulator that is active in the phagolysosome environment [69]. This mechanism could allow $S$. aureus to interfere with antigen processing and presentation on the MHC class II of the DCs, reducing their T cell-priming ability. Another effect of PSMs is the modulation of cytokine production by the host cells [118-120]. In DCs, the activation of the p38-CREB pathway by the PSMs induces a tolerogenic phenotype with a reduction 
of TLR2 signaling and production of inflammatory cytokines, leading to an increased priming of anti-inflammatory $\mathrm{T}_{\text {regs }}[118,119]$. After escaping the phagosome, $S$. aureus is able to replicate in the cytosol and induce host cell death or survive in a dormant state for extended time periods in the shape of small colony variants (SCV) [69]. This ability is probably linked to the chronicity of infections. It is still unclear what determines the balance between killing the host cell and surviving inside. Chronic S. aureus infection are very difficult to treat, and novel approaches are required. Chloroquine improved clearance of $S$. aureus from lung epithelial cells in combination with antibiotic therapy [121,122].

Autophagy or, more precisely, xenophagy, is used by DCs to kill pathogens and present antigens, once the bacteria have escaped into the cytoplasm. The cytoplasmic invaders become surrounded by double-membrane vacuoles, named autophagosomes, which present microtubule-associated protein 1 light chain 3 (LC3) associated to phosphatidylethanolamine (LC3-II). These fuse with lysosomes, redirecting their cargo from the cytoplasm back into the lysosomal pathway, followed by digestion and presentation of antigenic proteins. Consequently, peptides derived from cytoplasmic antigens, which are usually presented on the MHC class I, are loaded onto the MHC class II molecules, a process known as cross-presentation of antigens.

The agr system conditions $S$. aureus survival during autophagy by preventing the fusion between autophagosomes and lysosomes. S. aureus strains with a highly active agr system are not killed in autophagosomes in vitro and display an extended intracellular survival within phagocytes in vivo [31]. S. aureus can prevent fusion of autophagosomes with lysosomes via a novel mechanism, involving activation of MAPK14 and ATG5 phosphorylation [123]. Autophagy can tolerize host cells to the effects of alpha-toxin (alpha-hemolysin, Hla), another pore-forming toxin produced by S. aureus under agr control [124]. Indeed, autophagy allows cells to recycle membranes affected by Hla and endure higher concentrations of pore-forming toxins. Remarkably, Hla has been identified as an important autophagy-inducing factor $[31,125]$.

As previously mentioned, DCs produce cytokines to control the immune response, recruit immune cells on the infection site and activate T cells. S. aureus is able to modulate the cytokine production of immune cells with several mechanisms. The ESAT-6-like secretion system (Ess) is encoded in the conserved ess gene cluster [126]. The ess-encoded virulence factor EsxA dampens the pro-apoptotic response in infected DCs and may allow S. aureus to use these cells as a Trojan horse. EsxB dampens the production of regulatory and pro-inflammatory cytokines by the infected DCs, resulting in a reduced production of IFN- $\gamma$ and IL-17 by activated CD4+ T cells [127].

S. aureus can also induce an overstimulation of the immune system by secreting superantigens [128]. The species harbors 25 genes encoding superantigens, comprising the toxic shock syndrome toxin-1 (TSST-1) and the staphylococcal enterotoxins, organized in the "enterotoxin gene cluster" egc or on mobile genetic elements $[129,130]$. As superantigens, they are able to interact with the MHC class II on the DCs and the V $\beta$ region of the T cell receptor (TCR), bypassing the conventional antigen specific activation of $\mathrm{T}$ cells, to activate up to $20 \%$ of the $\mathrm{T}$ cell population [131].

\section{Interaction of DCs with S. aureus in the Respiratory Tract}

The airways are a site of extensive interaction between S. aureus and its host with extremely diverse outcome. Around 25 to $35 \%$ of adults persistently carry S. aureus in the nose, while the remainder is able to rapidly clear the bacteria from the upper airways [132]. However, S. aureus can also cause pneumonia, a life-threatening infection of the lungs. It may be community acquired, often in the context of an influenza infection, in which case the mortality rate can increase to $50 \%$ [133]. In hospitals, patients receiving mechanical ventilation are vulnerable to $S$. aureus infection and develop so-called ventilation-associated pneumonia. There is increasing evidence that, besides commensal and invasive behavior, S. aureus may also drive allergic airway inflammation $[134,135]$. Colonization with S. aureus is associated with childhood wheezing and asthma [136]. van Zele et al. have found that $66.7 \%$ of patients with nasal polys and co-morbid asthma are colonized with S. aureus, in contrast to $33.3 \%$ of healthy adults. In case of additional aspirin hypersensitivity, these were even $87.5 \%$ [137]. 
Moreover, IgE antibodies specific for S. aureus enterotoxins and serine protease-like proteins were found in asthmatic patients $[138,139]$.

DCs play a critical role in shaping the adaptive immune response at mucosal sites. The modulation of the $T$ helper cell response to $S$. aureus infection by lung DCs is of particular interest. Over the past years, many subsets of DCs have been described in lung immunity. Under steady state conditions, "immature" DCs in the lungs efficiently recognize and capture inhaled materials. DCs that have encountered antigens or allergens undergo maturation, leave the lung and migrate to draining regional lymphoid tissues, where they present the processed antigenic peptides to naïve $T$ cells. This results in T cell activation and polarization, depending on the nature of the antigen [140]. It has been well documented that DCs induce protective immune responses against pathogens, but may also initiate inflammatory immune responses to harmless allergens, being thus involved in the pathophysiology of asthma and allergic rhinitis [141]. Both protection and allergy are relevant in the interaction of S. aureus with its host.

S. aureus-primed $\mathrm{cDCs}$ are highly responsive and induce $\mathrm{T}$ cell differentiation into IFN- $\gamma$-producing CD4+ (Th1) and CD8+ (Tc1) cells [142]. In fact, healthy donors and patients show a large pool of $S$. aureus-specific memory $\mathrm{T}$ cells that respond to $S$. aureus with the secretion of IFN- $\gamma$ and/or IL-17 [21,22]. The existence of CD8+ T cell memory cells and their responses against staphylococcal antigens are important for minimizing inflammation and promoting $\mathrm{T}$ cell tolerance [20]. Moreover, long-term exposure of mice to $S$. aureus failed to produce IL-2 after an antigen-specific T cell response, suggesting that $\mathrm{T}$ cells undergo anergy during persistent infection [143]. The lungs are vulnerable to inflammation-induced organ damage interfering with gas exchange, which may rapidly become critical. A strong $\mathrm{T}$ cell response driven by $\mathrm{DC}$ recognition of $S$. aureus is therefore a double-edged sword, as has been demonstrated in murine pneumonia models (reviewed in [144]).

S. aureus colonization of the airways is associated with allergic airway disease, but the mechanisms of allergic sensitization or exacerbation by S. aureus are still poorly understood [136,145]. Asthma is defined by chronic airway inflammation with reversible airway obstruction, airway hyperresponsiveness, infiltration Th2 cells and eosinophils into the airway submucosa, mucus hypersecretion and airway remodeling. It has been more than two decades since Robinson et al. and other groups demonstrated that atopic asthma was associated with activation of Th2 type of $T$ cell in the airways [146]. In addition, in murine model of asthma and allergy, adoptive transfer of Th2 cells, but not Th1 cells, induces airway hyper-responsiveness (AHR) [147]. The involvement of DCs in asthma was characterized in 1998 by Lambrecht et al. [148], who showed that cDCs were essential for triggering allergy in ovalbumin-sensitized mice (OVA). Conversely, pDCs were protective [141]. Recently, it has been demonstrated that a subtype of cDCs, CD117+CD172 $\alpha+$, is a major mediator of inflammation in asthma by promoting the induction of Th2 immunity in spleens [149].

Some airborne allergens such as Der $\mathrm{p} 1$ from house dust mites disrupt the epithelial barrier by cleaving the tight junction proteins, thus gaining access to the DCs at the basolateral side of the epithelium [150]. It is tempting to speculate that $S$. aureus alpha-toxin (hemolysin alpha, Hla) may act similarly, because the pore-forming toxin activates the host metalloprotease ADAM10, which destroys epithelial adherens junctions [151,152]. Moreover, ADAM10 and its ligand Notch1 were shown to be essential for DCs to produce Th2 type cytokines in a murine model of IgE-mediated anaphylaxis, suggesting that ADAM10 activation by Hla could have pro-allergenic effects [153]. On the other hand, human Hla-specific T cells release mainly IFN- $\gamma$ and IL-17, indicating that the toxin itself is not an allergen [21,154-156]. It is not known how Hla affects DCs, but in monocytes the toxin is able to induce IL-17, which is in line with the observed cytokine profiles of Hla-specific T cells [151]. While questions remain regarding the possible pro-allergenic effects of Hla, there can be no doubt that the toxin is a decisive virulence factor in S. aureus pneumonia $[151,157]$. Via ADAM10 the toxin induces the secretion of pro-inflammatory cytokines and cell death via the nucleotide-binding domain and leucine-rich repeat containing gene family, pyrin domain containing 3 (NLRP3) inflammasome [158]. In the lungs, epithelial tissue destruction could provide host-borne nutrients for bacterial growth, which may be 
one reason for the disastrous effects of Hla in pneumonia [159]. Neutralization of S. aureus alpha toxin is under development as adjunct therapy with standard antibiotic treatment [151,160].

It was discovered that two classes of S. aureus proteins, SEs and serine protease-like proteins (Spls), readily cause allergic sensitization in the airways [161]. Affected humans and experimental animals elaborate antigen-specific IgE as well as Th2 cells $[139,162]$. This demonstrates that different $S$. aureus factors can elicit adaptive immune responses of different quality in the same individual. Similar observations have recently been reported for fungal antigens by Bacher et al. [163]. We conclude that many microbial proteins have adjuvant activity, determining the cytokine and antibody profiles of the specific $\mathrm{T}$ and $\mathrm{B}$ cells. As this is an emerging topic, there are many open questions: How are DCs involved in the process? Are the superantigenic or enzymatic activities of the staphylococcal factors important for their allergenic properties? Are there general features of bacterial allergens? How does intrinsic adjuvanticity of bacterial antigens affect the outcome of vaccination, especially, if non-adjuvanted bacterial factors are used as vaccines? Is S. aureus able to initiate the allergic march in susceptible individuals, or does it merely exacerbate pre-existing allergic inflammation? We hypothesize that $S$. aureus allergens may sensitize vulnerable persons whose allergic reaction is then potentiated by bacterial toxins and the PAMPs in the airways.

\section{Conclusions}

Coordination of the immune response at the interface between innate and adaptive defense mechanisms is an essential function of DCs. These phagocytic leukocytes sense microorganisms in tissues which border on the external environment. Not surprisingly, S. aureus has evolved means to prevent phagocytosis, to resist killing inside phagosomes, and manipulate DCs to its advantage. The multifaceted interactions between $S$. aureus and its host take place in the airways. The outcomes range from rapid clearance through symptom-free colonization to asthma or life-threatening pneumonia. Remarkably, single $S$. aureus proteins can elicit immune responses of distinctive cytokine and antibody profiles in the same individual, demonstrating that bacterial antigens have adjuvant properties. It will be worthwhile exploring more closely how DCs affect these processes and how their response is determined by various $S$. aureus virulence factors. A better understanding of the behavior of DCs, pivots of the immune system exhibiting great plasticity, will also benefit vaccine research.

Author Contributions: M.N.D., M.N., B.M.B. and V.P. wrote the manuscript.

Funding: This group's work was supported by grants from the German Research Foundation (TRR34, GRK840 and GRK1870), the German Ministry of Education and Research (Medical Infection Genomics, HICARE, InfectControl2020), Federal Excellence Initiative of Mecklenburg Western Pomerania and The European Social Fund (ESF) (Grants KoInfekt and Card-ii-Omics ESF_14-BM-A55-00xx_16).

Acknowledgments: We thank the members of our laboratory and our colleagues for inspiring discussions and their contributions to our understanding of the adaptive immune response to S. aureus and apologize to all those whose work could not be described due to space limitations.

Conflicts of Interest: The authors declare no conflict of interest.

\section{References}

1. Thammavongsa, V.; Kim, H.K.; Missiakas, D.; Schneewind, O. Staphylococcal manipulation of host immune responses. Nat. Rev. Microbiol. 2015, 13, 529-543. [CrossRef] [PubMed]

2. Feng, C.H.; Miller, M.D.; Simon, R.A. The united allergic airway: Connections between allergic rhinitis, asthma, and chronic sinusitis. Am. J. Rhinol. Allergy 2012, 26, 187-190. [CrossRef] [PubMed]

3. Abu-Humaidan, A.H.; Elvén, M.; Sonesson, A.; Garred, P.; Sørensen, O.E. Persistent Intracellular Staphylococcus aureus in Keratinocytes Lead to Activation of the Complement System with Subsequent Reduction in the Intracellular Bacterial Load. Front. Immunol. 2018, 9, 396. [CrossRef] [PubMed]

4. Nagl, M.; Kacani, L.; Müllauer, B.; Lemberger, E.-M.; Stoiber, H.; Sprinzl, G.M.; Schennach, H.; Dierich, M.P. Phagocytosis and Killing of Bacteria by Professional Phagocytes and Dendritic Cells. Clin. Diagn. Lab. Immunol. 2002, 9, 1165-1168. [CrossRef] [PubMed] 
5. Schindler, D.; Gutierrez, M.G.; Beineke, A.; Rauter, Y.; Rohde, M.; Foster, S.; Goldmann, O.; Medina, E. Dendritic cells are central coordinators of the host immune response to Staphylococcus aureus bloodstream infection. Am. J. Pathol. 2012, 181, 1327-1337. [CrossRef] [PubMed]

6. Van Kessel, K.P.M.; Bestebroer, J.; van Strijp, J.A.G. Neutrophil-Mediated Phagocytosis of Staphylococcus aureus. Front. Immunol. 2014, 5, 467. [CrossRef] [PubMed]

7. Berends, E.T.M.; Horswill, A.R.; Haste, N.M.; Monestier, M.; Nizet, V.; Köckritz-Blickwede, M. von. Nuclease expression by Staphylococcus aureus facilitates escape from neutrophil extracellular traps. J. Innate Immun. 2010, 2, 576-586. [CrossRef] [PubMed]

8. Laarman, A.; Milder, F.; van Strijp, J.; Rooijakkers, S. Complement inhibition by gram-positive pathogens: Molecular mechanisms and therapeutic implications. J. Mol. Med. 2010, 88, 115-120. [CrossRef] [PubMed]

9. Rooijakkers, S.H.M.; van Kessel, K.P.M.; van Strijp, J.A.G. Staphylococcal innate immune evasion. Trends Microbiol. 2005, 13, 596-601. [CrossRef] [PubMed]

10. Von Köckritz-Blickwede, M.; Konrad, S.; Foster, S.; Gessner, J.E.; Medina, E. Protective role of complement C5a in an experimental model of Staphylococcus aureus bacteremia. J. Innate Immun. 2010, 2, 87-92. [CrossRef] [PubMed]

11. Na, M.; Jarneborn, A.; Ali, A.; Welin, A.; Magnusson, M.; Stokowska, A.; Pekna, M.; Jin, T. Deficiency of the Complement Component 3 but Not Factor B Aggravates Staphylococcus aureus Septic Arthritis in Mice. Infect. Immun. 2016, 84, 930-939. [CrossRef] [PubMed]

12. Bröker, B.M.; Holtfreter, S.; Bekeredjian-Ding, I. Immune control of Staphylococcus aureus_Regulation and counter-regulation of the adaptive immune response. Int J. Med. Microbiol. 2014, 304, 204-214. [CrossRef] [PubMed]

13. Holtfreter, S.; Kolata, J.; Bröker, B.M. Towards the immune proteome of Staphylococcus aureus-The anti-S. aureus antibody response. Int. J. Med. Microbiol. 2010, 300, 176-192. [CrossRef] [PubMed]

14. Stentzel, S.; Sundaramoorthy, N.; Michalik, S.; Nordengrün, M.; Schulz, S.; Kolata, J.; Kloppot, P.; Engelmann, S.; Steil, L.; Hecker, M.; et al. Specific serum IgG at diagnosis of Staphylococcus aureus bloodstream invasion is correlated with disease progression. J. Proteom. 2015, 128, 1-7. [CrossRef] [PubMed]

15. Stentzel, S.; Hagl, B.; Abel, F.; Kahl, B.C.; Rack-Hoch, A.; Bröker, B.M.; Renner, E.D. Reduced Immunoglobulin (Ig) G Response to Staphylococcus aureus in STAT3 Hyper-IgE Syndrome. Clin. Infect. Dis. 2017, 64, 1279-1282. [CrossRef] [PubMed]

16. Farmand, S.; Sundin, M. Hyper-IgE syndromes: Recent advances in pathogenesis, diagnostics and clinical care. Curr. Opin. Hematol. 2015, 22, 12-22. [CrossRef] [PubMed]

17. Spellberg, B.; Guidos, R.; Gilbert, D.; Bradley, J.; Boucher, H.W.; Scheld, W.M.; Bartlett, J.G.; Edwards, J. The epidemic of antibiotic-resistant infections: A call to action for the medical community from the Infectious Diseases Society of America. Clin. Infect. Dis. 2008, 46, 155-164. [CrossRef] [PubMed]

18. Archer, N.K.; Harro, J.M.; Shirtliff, M.E. Clearance of Staphylococcus aureus nasal carriage is T cell dependent and mediated through interleukin-17A expression and neutrophil influx. Infect. Immun. 2013, 81, 2070-2075. [CrossRef] [PubMed]

19. Minegishi, Y.; Saito, M.; Nagasawa, M.; Takada, H.; Hara, T.; Tsuchiya, S.; Agematsu, K.; Yamada, M.; Kawamura, N.; Ariga, T.; et al. Molecular explanation for the contradiction between systemic Th17 defect and localized bacterial infection in hyper-IgE syndrome. J. Exp. Med. 2009, 206, 1291-1301. [CrossRef] [PubMed]

20. Uebele, J.; Stein, C.; Nguyen, M.-T.; Schneider, A.; Kleinert, F.; Tichá, O.; Bierbaum, G.; Götz, F.; Bekeredjian-Ding, I. Antigen delivery to dendritic cells shapes human CD4+ and CD8+ T cell memory responses to Staphylococcus aureus. PLoS Pathog. 2017, 13, e1006387. [CrossRef] [PubMed]

21. Kolata, J.B.; Kühbandner, I.; Link, C.; Normann, N.; Vu, C.H.; Steil, L.; Weidenmaier, C.; Bröker, B.M. The Fall of a Dogma? Unexpected High T-Cell Memory Response to Staphylococcus aureus in Humans. J. Infect. Dis. 2015, 212, 830-838. [CrossRef] [PubMed]

22. Brown, A.F.; Murphy, A.G.; Lalor, S.J.; Leech, J.M.; O’Keeffe, K.M.; Mac Aogáin, M.; O’Halloran, D.P.; Lacey, K.A.; Tavakol, M.; Hearnden, C.H.; et al. Memory Th1 Cells Are Protective in Invasive Staphylococcus aureus Infection. PLoS Pathog. 2015, 11, e1005226. [CrossRef] [PubMed]

23. Langerhans, P. Ueber die Nerven der menschlichen Haut. Arch. Pathol. Anat. 1868, 44, 325-337. [CrossRef]

24. Steinman, R.M. Identification of a novel cell type in peripheral lymphoid organs of mice: I. Morphology, quantitation, tissue distribution. J. Exp. Med. 1973, 137, 1142-1162. [CrossRef] [PubMed] 
25. Janeway, C.A.; Medzhitov, R. Innate immune recognition. Annu. Rev. Immunol. 2002, 20, 197-216. [CrossRef] [PubMed]

26. Banchereau, J.; Steinman, R.M. Dendritic cells and the control of immunity. Nature 1998, 392, $245-252$. [CrossRef] [PubMed]

27. Steinman, R.M. The dendritic cell system and its role in immunogenicity. Annu. Rev. Immunol. 1991, 9, 271-296. [CrossRef] [PubMed]

28. Steinman, R.M.; Hawiger, D.; Nussenzweig, M.C. Tolerogenic dendritic cells. Annu. Rev. Immunol. 2003, 21, 685-711. [CrossRef] [PubMed]

29. Kelly, B.; O'Neill, L.A.J. Metabolic reprogramming in macrophages and dendritic cells in innate immunity. Cell Res. 2015, 25, 771-784. [CrossRef] [PubMed]

30. Savina, A.; Amigorena, S. Phagocytosis and antigen presentation in dendritic cells. Immunol. Rev. 2007, 219, 143-156. [CrossRef] [PubMed]

31. O'Keeffe, K.M.; Wilk, M.M.; Leech, J.M.; Murphy, A.G.; Laabei, M.; Monk, I.R.; Massey, R.C.; Lindsay, J.A.; Foster, T.J.; Geoghegan, J.A.; et al. Manipulation of Autophagy in Phagocytes Facilitates Staphylococcus aureus Bloodstream Infection. Infect. Immun. 2015, 83, 3445-3457. [CrossRef] [PubMed]

32. Jung, J.-Y.; Roberts, L.L.; Robinson, C.M. The presence of interleukin-27 during monocyte-derived dendritic cell differentiation promotes improved antigen processing and stimulation of T cells. Immunology 2015, 144, 649-660. [CrossRef] [PubMed]

33. Nishat, S.; Wuescher, L.M.; Worth, R.G. Platelets enhance dendritic cell responses against S. aureus through CD40-CD40L interactions. Infect. Immun. 2018. [CrossRef] [PubMed]

34. Schraml, B.U.; Reis e Sousa, C. Defining dendritic cells. Curr. Opin. Immunol. 2015, 32, 13-20. [CrossRef] [PubMed]

35. Hart, D.N. Dendritic cells: Unique leukocyte populations which control the primary immune response. Blood 1997, 90, 3245-3287. [PubMed]

36. Ueno, H.; Klechevsky, E.; Morita, R.; Aspord, C.; Cao, T.; Matsui, T.; Di Pucchio, T.; Connolly, J.; Fay, J.W.; Pascual, V.; et al. Dendritic cell subsets in health and disease. Immunol. Rev. 2007, 219, 118-142. [CrossRef] [PubMed]

37. Steinman, R.M.; Cohn, Z.A. Identification of a novel cell type in peripheral lymphoid organs of mice: II. Functional properties in vitro. J. Exp. Med. 1974, 139, 380-397. [CrossRef] [PubMed]

38. Steinman, R.M.; Lustig, D.S.; Cohn, Z.A. Identification of a novel cell type in peripheral lymphoid organs of mice: III. Functional properties in vivo. J. Exp. Med. 1974, 139, 1431-1445. [CrossRef] [PubMed]

39. Lennert, K.; Remmele, W. Karyometrische Untersuchungen an Lymphknotenzellen des Menschen. Acta Haematol. 2004, 19, 99-113. [CrossRef] [PubMed]

40. Liu, K.; Victora, G.D.; Schwickert, T.A.; Guermonprez, P.; Meredith, M.M.; Yao, K.; Chu, F.-F.; Randolph, G.J.; Rudensky, A.Y.; Nussenzweig, M. In Vivo Analysis of Dendritic Cell Development and Homeostasis. Science 2009, 324, 392-397. [CrossRef] [PubMed]

41. Yamazaki, C.; Sugiyama, M.; Ohta, T.; Hemmi, H.; Hamada, E.; Sasaki, I.; Fukuda, Y.; Yano, T.; Nobuoka, M.; Hirashima, T.; et al. Critical roles of a dendritic cell subset expressing a chemokine receptor, XCR1. J. Immunol. 2013, 190, 6071-6082. [CrossRef] [PubMed]

42. Merad, M.; Sathe, P.; Helft, J.; Miller, J.; Mortha, A. The dendritic cell lineage: Ontogeny and function of dendritic cells and their subsets in the steady state and the inflamed setting. Annu. Rev. Immunol. 2013, 31, 563-604. [CrossRef] [PubMed]

43. Dress, R.J.; Wong, A.Y.W.; Ginhoux, F. Homeostatic control of dendritic cell numbers and differentiation. Immunol. Cell Boil. 2018, 96, 463-476. [CrossRef] [PubMed]

44. McGovern, N.; Schlitzer, A.; Gunawan, M.; Jardine, L.; Shin, A.; Poyner, E.; Green, K.; Dickinson, R.; Wang, X.-N.; Low, D.; et al. Human Dermal CD14 + Cells Are a Transient Population of Monocyte-Derived Macrophages. Immunity 2014, 41, 465-477. [CrossRef] [PubMed]

45. Bandola-Simon, J.; Roche, P.A. Dysfunction of antigen processing and presentation by dendritic cells in cancer. Mol. Immunol. 2018. [CrossRef] [PubMed]

46. Collin, M.; Bigley, V. Human dendritic cell subsets: An update. Immunology 2018, 154, 3-20. [CrossRef] [PubMed] 
47. Grouard, G.; Rissoan, M.-C.; Filgueira, L.; Durand, I.; Banchereau, J.; Liu, Y.-J. The Enigmatic Plasmacytoid T Cells Develop into Dendritic Cells with Interleukin (IL)-3 and CD40-Ligand. J. Exp. Med. 1997, 185, 1101-1112. [CrossRef] [PubMed]

48. Rissoan, M.C.; Soumelis, V.; Kadowaki, N.; Grouard, G.; Briere, F.; de Waal Malefyt, R.; Liu, Y.J. Reciprocal control of T helper cell and dendritic cell differentiation. Science 1999, 283, 1183-1186. [CrossRef] [PubMed]

49. Wollenberg, A.; Günther, S.; Moderer, M.; Wetzel, S.; Wagner, M.; Towarowski, A.; Tuma, E.; Rothenfusser, S.; Endres, S.; Hartmann, G. Plasmacytoid Dendritic Cells: A New Cutaneous Dendritic Cell Subset with Distinct Role in Inflammatory Skin Diseases. J. Investig. Dermatol. 2002, 119, 1096-1102. [CrossRef] [PubMed]

50. MacDonald, K.P.A. Characterization of human blood dendritic cell subsets. Blood 2002, 100, 4512-4520. [CrossRef] [PubMed]

51. Onai, N.; Kurabayashi, K.; Hosoi-Amaike, M.; Toyama-Sorimachi, N.; Matsushima, K.; Inaba, K.; Ohteki, T. A Clonogenic Progenitor with Prominent Plasmacytoid Dendritic Cell Developmental Potential. Immunity 2013, 38, 943-957. [CrossRef] [PubMed]

52. Kamath, A.T.; Pooley, J.; O'Keeffe, M.A.; Vremec, D.; Zhan, Y.; Lew, A.M.; D'Amico, A.; Wu, L.; Tough, D.F.; Shortman, K. The development, maturation, and turnover rate of mouse spleen dendritic cell populations. J. Immunol. 2000, 165, 6762-6770. [CrossRef] [PubMed]

53. Fonteneau, J.-F. Activation of influenza virus-specific CD4+ and CD8+ T cells: A new role for plasmacytoid dendritic cells in adaptive immunity. Blood 2003, 101, 3520-3526. [CrossRef] [PubMed]

54. Kool, M.; van Nimwegen, M.; Willart, M.A.M.; Muskens, F.; Boon, L.; Smit, J.J.; Coyle, A.; Clausen, B.E.; Hoogsteden, H.C.; Lambrecht, B.N.; et al. An anti-inflammatory role for plasmacytoid dendritic cells in allergic airway inflammation. J. Immunol. 2009, 183, 1074-1082. [CrossRef] [PubMed]

55. Iwasaki, A.; Medzhitov, R. Control of adaptive immunity by the innate immune system. Nat. Immunol. 2015, 16, 343-353. [CrossRef] [PubMed]

56. Hanzelmann, D.; Joo, H.-S.; Franz-Wachtel, M.; Hertlein, T.; Stevanovic, S.; Macek, B.; Wolz, C.; Götz, F.; Otto, M.; Kretschmer, D.; et al. Toll-like receptor 2 activation depends on lipopeptide shedding by bacterial surfactants. Nat. Commun. 2016, 7, 12304. [CrossRef] [PubMed]

57. Fournier, B.; Philpott, D.J. Recognition of Staphylococcus aureus by the innate immune system. Clin. Microbiol. Rev. 2005, 18, 521-540. [CrossRef] [PubMed]

58. Fournier, B. The function of TLR2 during staphylococcal diseases. Front. Cell. Infect. Microbiol. 2012, 2, 167. [CrossRef] [PubMed]

59. Koymans, K.J.; Feitsma, L.J.; Brondijk, T.H.C.; Aerts, P.C.; Lukkien, E.; Lössl, P.; van Kessel, K.P.M.; de Haas, C.J.C.; van Strijp, J.A.G.; Huizinga, E.G. Structural basis for inhibition of TLR2 by staphylococcal superantigen-like protein 3 (SSL3). Proc. Natl. Acad. Sci. USA 2015, 112, 11018-11023. [CrossRef] [PubMed]

60. Koymans, K.J.; Goldmann, O.; Karlsson, C.A.Q.; Sital, W.; Thänert, R.; Bisschop, A.; Vrieling, M.; Malmström, J.; van Kessel, K.P.M.; de Haas, C.J.C.; et al. The TLR2 Antagonist Staphylococcal Superantigen-Like Protein 3 Acts as a Virulence Factor to Promote Bacterial Pathogenicity in vivo. J. Innate Immun. 2017, 9, 561-573. [CrossRef] [PubMed]

61. Iwamoto, K.; Stroisch, T.J.; Koch, S.; Herrmann, N.; Leib, N.; Bieber, T. Langerhans and inflammatory dendritic epidermal cells in atopic dermatitis are tolerized towards TLR2 activation. Allergy 2018. [CrossRef] [PubMed]

62. Aoyagi, S.; Oda, T.; Wada, K.; Nakamura, E.; Kosuga, T.; Yasunaga, H. Infective Endocarditis Associated with Atopic Dermatitis. Int. Heart J. 2018, 59, 420-423. [CrossRef] [PubMed]

63. Bergstrøm, B.; Aune, M.H.; Awuh, J.A.; Kojen, J.F.; Blix, K.J.; Ryan, L.; Flo, T.H.; Mollnes, T.E.; Espevik, T.; Stenvik, J. TLR8 Senses Staphylococcus aureus RNA in Human Primary Monocytes and Macrophages and Induces IFN- $\beta$ Production via a TAK1-IKK $\beta$-IRF5 Signaling Pathway. J. Immunol. 2015, 195, 1100-1111. [CrossRef] [PubMed]

64. Ugolini, M.; Gerhard, J.; Burkert, S.; Jensen, K.J.; Georg, P.; Ebner, F.; Volkers, S.M.; Thada, S.; Dietert, K.; Bauer, L.; et al. Recognition of microbial viability via TLR8 drives TFH cell differentiation and vaccine responses. Nat. Immunol. 2018, 19, 386-396. [CrossRef] [PubMed]

65. Parker, D.; Prince, A. Staphylococcus aureus induces type I IFN signaling in dendritic cells via TLR9. J. Immunol. 2012, 189, 4040-4046. [CrossRef] [PubMed] 
66. Mohamed, W.; Domann, E.; Chakraborty, T.; Mannala, G.; Lips, K.S.; Heiss, C.; Schnettler, R.; Alt, V. TLR9 mediates S. aureus killing inside osteoblasts via induction of oxidative stress. BMC Microbiol. 2016, 16, 230. [CrossRef] [PubMed]

67. Mansur, N.; Hazzan, R.; Paul, M.; Bishara, J.; Leibovici, L. Does sex affect 30-day mortality in Staphylococcus aureus bacteremia? Gend. Med. 2012, 9, 463-470. [CrossRef] [PubMed]

68. Nurjadi, D.; Heeg, K.; Weber, A.N.R.; Zanger, P. Toll-like receptor 9 (TLR-9) promotor polymorphisms and gene expression are associated with persistent Staphylococcus aureus nasal carriage. Clin. Microbiol. Infect. 2018. [CrossRef] [PubMed]

69. Fraunholz, M.; Sinha, B. Intracellular Staphylococcus aureus: Live-in and let die. Front. Cell. Infect. Microbiol. 2012, 2, 43. [CrossRef] [PubMed]

70. Foster, T.J.; Geoghegan, J.A.; Ganesh, V.K.; Höök, M. Adhesion, invasion and evasion: The many functions of the surface proteins of Staphylococcus aureus. Nat. Rev. Microbiol. 2014, 12, 49-62. [CrossRef] [PubMed]

71. Strobel, M.; Pförtner, H.; Tuchscherr, L.; Völker, U.; Schmidt, F.; Kramko, N.; Schnittler, H.-J.; Fraunholz, M.J.; Löffler, B.; Peters, G.; et al. Post-invasion events after infection with Staphylococcus aureus are strongly dependent on both the host cell type and the infecting S. aureus strain. Clin. Microbiol. Infect. 2016, 22, 799-809. [CrossRef] [PubMed]

72. Patti, J.M.; Allen, B.L.; McGavin, M.J.; Höök, M. MSCRAMM-mediated adherence of microorganisms to host tissues. Annu. Rev. Microbiol. 1994, 48, 585-617. [CrossRef] [PubMed]

73. Sinha, B.; François, P.P.; Nüsse, O.; Foti, M.; Hartford, O.M.; Vaudaux, P.; Foster, T.J.; Lew, D.P.; Herrmann, M.; Krause, K.H. Fibronectin-binding protein acts as Staphylococcus aureus invasin via fibronectin bridging to integrin alpha5beta1. Cell. Microbiol. 1999, 1, 101-117. [CrossRef] [PubMed]

74. Schwarz-Linek, U.; Werner, J.M.; Pickford, A.R.; Gurusiddappa, S.; Kim, J.H.; Pilka, E.S.; Briggs, J.A.G.; Gough, T.S.; Höök, M.; Campbell, I.D.; et al. Pathogenic bacteria attach to human fibronectin through a tandem beta-zipper. Nature 2003, 423, 177-181. [CrossRef] [PubMed]

75. Porayath, C.; Suresh, M.K.; Biswas, R.; Nair, B.G.; Mishra, N.; Pal, S. Autolysin mediated adherence of Staphylococcus aureus with Fibronectin, Gelatin and Heparin. Int. J. Biol. Macromol. 2018, 110, 179-184. [CrossRef] [PubMed]

76. Chavakis, E.; Aicher, A.; Heeschen, C.; Sasaki, K.-i.; Kaiser, R.; El Makhfi, N.; Urbich, C.; Peters, T.; Scharffetter-Kochanek, K.; Zeiher, A.M.; et al. Role of beta2-integrins for homing and neovascularization capacity of endothelial progenitor cells. J. Exp. Med. 2005, 201, 63-72. [CrossRef] [PubMed]

77. Hussain, M.; von Eiff, C.; Sinha, B.; Joost, I.; Herrmann, M.; Peters, G.; Becker, K. Eap Gene as novel target for specific identification of Staphylococcus aureus. J. Clin. Microbiol. 2008, 46, 470-476. [CrossRef] [PubMed]

78. McAdow, M.; Kim, H.K.; Dedent, A.C.; Hendrickx, A.P.A.; Schneewind, O.; Missiakas, D.M. Preventing sepsis through the inhibition of its agglutination in blood. PLoS Pathog. 2011, 7, e1002307. [CrossRef] [PubMed]

79. Guilliams, M.; Bruhns, P.; Saeys, Y.; Hammad, H.; Lambrecht, B.N. The function of Fc $\gamma$ receptors in dendritic cells and macrophages. Nat. Rev. Immunol. 2014, 14, 94-108. [CrossRef] [PubMed]

80. Kuipers, A.; Stapels, D.A.C.; Weerwind, L.T.; Ko, Y.-P.; Ruyken, M.; Lee, J.C.; van Kessel, K.P.M.; Rooijakkers, S.H.M. The Staphylococcus aureus polysaccharide capsule and Efb-dependent fibrinogen shield act in concert to protect against phagocytosis. Microbiology 2016, 162, 1185-1194. [CrossRef] [PubMed]

81. O'Riordan, K.; Lee, J.C. Staphylococcus aureus Capsular Polysaccharides. Clin. Microbiol. Rev. 2004, 17, 218-234. [CrossRef] [PubMed]

82. Becker, S.; Frankel, M.B.; Schneewind, O.; Missiakas, D. Release of protein A from the cell wall of Staphylococcus aureus. Proc. Natl. Acad. Sci. USA 2014, 111, 1574-1579. [CrossRef] [PubMed]

83. Goodyear, C.S.; Silverman, G.J. Staphylococcal toxin induced preferential and prolonged in vivo deletion of innate-like B lymphocytes. Proc. Natl. Acad. Sci. USA 2004, 101, 11392-11397. [CrossRef] [PubMed]

84. Lukácsi, S.; Nagy-Baló, Z.; Erdei, A.; Sándor, N.; Bajtay, Z. The role of CR3 (CD11b/CD18) and CR4 (CD11c/CD18) in complement-mediated phagocytosis and podosome formation by human phagocytes. Immunol. Lett. 2017, 189, 64-72. [CrossRef] [PubMed]

85. Pietrocola, G.; Nobile, G.; Rindi, S.; Speziale, P. Staphylococcus aureus Manipulates Innate Immunity through Own and Host-Expressed Proteases. Front. Cell. Infect. Microbiol. 2017, 7, 787. [CrossRef] [PubMed] 
86. Laarman, A.J.; Ruyken, M.; Malone, C.L.; van Strijp, J.A.G.; Horswill, A.R.; Rooijakkers, S.H.M. Staphylococcus aureus metalloprotease aureolysin cleaves complement $C 3$ to mediate immune evasion. J. Immunol. 2011, 186, 6445-6453. [CrossRef] [PubMed]

87. Jin, T.; Bokarewa, M.; Foster, T.; Mitchell, J.; Higgins, J.; Tarkowski, A. Staphylococcus aureus Resists Human Defensins by Production of Staphylokinase, a Novel Bacterial Evasion Mechanism. J. Immunol. 2004, 172, 1169-1176. [CrossRef] [PubMed]

88. Sieprawska-Lupa, M.; Mydel, P.; Krawczyk, K.; Wojcik, K.; Puklo, M.; Lupa, B.; Suder, P.; Silberring, J.; Reed, M.; Pohl, J.; et al. Degradation of Human Antimicrobial Peptide LL-37 by Staphylococcus aureus-Derived Proteinases. Antimicrob. Agents Chemother. 2004, 48, 4673-4679. [CrossRef] [PubMed]

89. Noore, J.; Noore, A.; Li, B. Cationic antimicrobial peptide LL-37 is effective against both extra- and intracellular Staphylococcus aureus. Antimicrob. Agents Chemother. 2013, 57, 1283-1290. [CrossRef] [PubMed]

90. Spaan, A.N.; van Strijp, J.A.G.; Torres, V.J. Leukocidins: Staphylococcal bi-component pore-forming toxins find their receptors. Nat. Rev. Microbiol. 2017, 15, 435-447. [CrossRef] [PubMed]

91. Alonzo, F.; Kozhaya, L.; Rawlings, S.A.; Reyes-Robles, T.; DuMont, A.L.; Myszka, D.G.; Landau, N.R.; Unutmaz, D.; Torres, V.J. CCR5 is a receptor for Staphylococcus aureus leukotoxin ED. Nature 2013, 493, 51-55. [CrossRef] [PubMed]

92. Reyes-Robles, T.; Alonzo, F.; Kozhaya, L.; Lacy, D.B.; Unutmaz, D.; Torres, V.J. Staphylococcus aureus leukotoxin ED targets the chemokine receptors CXCR1 and CXCR2 to kill leukocytes and promote infection. Cell Host Microbe 2013, 14, 453-459. [CrossRef] [PubMed]

93. DuMont, A.L.; Yoong, P.; Day, C.J.; Alonzo, F.; McDonald, W.H.; Jennings, M.P.; Torres, V.J. Staphylococcus aureus LukAB cytotoxin kills human neutrophils by targeting the CD11b subunit of the integrin Mac-1. Proc. Natl. Acad. Sci. USA 2013, 110, 10794-10799. [CrossRef] [PubMed]

94. Ho, M.K.; Springer, T.A. Mac-1 antigen: Quantitative expression in macrophage populations and tissues, and immunofluorescent localization in spleen. J. Immunol. 1982, 128, 2281-2286. [PubMed]

95. DuMont, A.L.; Yoong, P.; Liu, X.; Day, C.J.; Chumbler, N.M.; James, D.B.A.; Alonzo, F.; Bode, N.J.; Lacy, D.B.; Jennings, M.P.; et al. Identification of a crucial residue required for Staphylococcus aureus LukAB cytotoxicity and receptor recognition. Infect. Immun. 2014, 82, 1268-1276. [CrossRef] [PubMed]

96. Vrieling, M.; Koymans, K.J.; Heesterbeek, D.A.C.; Aerts, P.C.; Rutten, V.P.M.G.; de Haas, C.J.C.; van Kessel, K.P.M.; Koets, A.P.; Nijland, R.; van Strijp, J.A.G. Bovine Staphylococcus aureus Secretes the Leukocidin LukMF' To Kill Migrating Neutrophils through CCR1. mBio 2015, 6, e00335. [CrossRef] [PubMed]

97. Sozzani, S.; Luini, W.; Borsatti, A.; Polentarutti, N.; Zhou, D.; Piemonti, L.; D'Amico, G.; Power, C.A.; Wells, T.N.; Gobbi, M.; et al. Receptor expression and responsiveness of human dendritic cells to a defined set of CC and CXC chemokines. J. Immunol. 1997, 159, 1993-2000. [PubMed]

98. Spaan, A.N.; Reyes-Robles, T.; Badiou, C.; Cochet, S.; Boguslawski, K.M.; Yoong, P.; Day, C.J.; de Haas, C.J.C.; van Kessel, K.P.M.; Vandenesch, F.; et al. Staphylococcus aureus Targets the Duffy Antigen Receptor for Chemokines (DARC) to Lyse Erythrocytes. Cell Host Microbe 2015, 18, 363-370. [CrossRef] [PubMed]

99. Spaan, A.N.; Vrieling, M.; Wallet, P.; Badiou, C.; Reyes-Robles, T.; Ohneck, E.A.; Benito, Y.; de Haas, C.J.C.; Day, C.J.; Jennings, M.P.; et al. The staphylococcal toxins $\gamma$-haemolysin AB and CB differentially target phagocytes by employing specific chemokine receptors. Nat. Commun. 2014, 5, 5438. [CrossRef] [PubMed]

100. Meyer, F.; Girardot, R.; Piémont, Y.; Prévost, G.; Colin, D.A. Analysis of the specificity of Panton-Valentine leucocidin and gamma-hemolysin F component binding. Infect. Immun. 2009, 77, 266-273. [CrossRef] [PubMed]

101. Dalla Serra, M.; Coraiola, M.; Viero, G.; Comai, M.; Potrich, C.; Ferreras, M.; Baba-Moussa, L.; Colin, D.A.; Menestrina, G.; Bhakdi, S.; et al. Staphylococcus aureus bicomponent gamma-hemolysins, HlgA, HlgB, and $\mathrm{HlgC}$, can form mixed pores containing all components. J. Chem. Inf. Model. 2005, 45, 1539-1545. [CrossRef] [PubMed]

102. Rybicka, J.M.; Balce, D.R.; Chaudhuri, S.; Allan, E.R.O.; Yates, R.M. Phagosomal proteolysis in dendritic cells is modulated by NADPH oxidase in a pH-independent manner. EMBO J. 2012, 31, 932-944. [CrossRef] [PubMed]

103. Ip, W.K.E.; Sokolovska, A.; Charriere, G.M.; Boyer, L.; Dejardin, S.; Cappillino, M.P.; Yantosca, L.M.; Takahashi, K.; Moore, K.J.; Lacy-Hulbert, A.; et al. Phagocytosis and phagosome acidification are required for pathogen processing and MyD88-dependent responses to Staphylococcus aureus. J. Immunol. 2010, 184, 7071-7081. [CrossRef] [PubMed] 
104. Horn, J.; Stelzner, K.; Rudel, T.; Fraunholz, M. Inside job: Staphylococcus aureus host-pathogen interactions. Int. J. Med. Microbiol. 2017. [CrossRef] [PubMed]

105. Bore, E.; Langsrud, S.; Langsrud, O.; Rode, T.M.; Holck, A. Acid-shock responses in Staphylococcus aureus investigated by global gene expression analysis. Microbiology 2007, 153, 2289-2303. [CrossRef] [PubMed]

106. Liu, G.Y.; Essex, A.; Buchanan, J.T.; Datta, V.; Hoffman, H.M.; Bastian, J.F.; Fierer, J.; Nizet, V. Staphylococcus aureus golden pigment impairs neutrophil killing and promotes virulence through its antioxidant activity. J. Exp. Med. 2005, 202, 209-215. [CrossRef] [PubMed]

107. Malachowa, N.; Kohler, P.L.; Schlievert, P.M.; Chuang, O.N.; Dunny, G.M.; Kobayashi, S.D.; Miedzobrodzki, J.; Bohach, G.A.; Seo, K.S. Characterization of a Staphylococcus aureus surface virulence factor that promotes resistance to oxidative killing and infectious endocarditis. Infect. Immun. 2011, 79, 342-352. [CrossRef] [PubMed]

108. Ballal, A.; Manna, A.C. Regulation of superoxide dismutase (sod) genes by SarA in Staphylococcus aureus. J. Bacteriol. 2009, 191, 3301-3310. [CrossRef] [PubMed]

109. Cosgrove, K.; Coutts, G.; Jonsson, I.-M.; Tarkowski, A.; Kokai-Kun, J.F.; Mond, J.J.; Foster, S.J. Catalase (KatA) and alkyl hydroperoxide reductase $(\mathrm{AhpC})$ have compensatory roles in peroxide stress resistance and are required for survival, persistence, and nasal colonization in Staphylococcus aureus. J. Bacteriol. 2007, 189, 1025-1035. [CrossRef] [PubMed]

110. De Jong, N.W.M.; Ramyar, K.X.; Guerra, F.E.; Nijland, R.; Fevre, C.; Voyich, J.M.; McCarthy, A.J.; Garcia, B.L.; van Kessel, K.P.M.; van Strijp, J.A.G.; et al. Immune evasion by a staphylococcal inhibitor of myeloperoxidase. Proc. Natl. Acad. Sci. USA 2017, 114, 9439-9444. [CrossRef] [PubMed]

111. Odobasic, D.; Kitching, A.R.; Yang, Y.; O'Sullivan, K.M.; Muljadi, R.C.M.; Edgtton, K.L.; Tan, D.S.Y.; Summers, S.A.; Morand, E.F.; Holdsworth, S.R. Neutrophil myeloperoxidase regulates T-cell-driven tissue inflammation in mice by inhibiting dendritic cell function. Blood 2013, 121, 4195-4204. [CrossRef] [PubMed]

112. Scholz, W.; Platzer, B.; Schumich, A.; Höcher, B.; Fritsch, G.; Knapp, W.; Strobl, H. Initial human myeloid/dendritic cell progenitors identified by absence of myeloperoxidase protein expression. Exp. Hematol. 2004, 32, 270-276. [CrossRef] [PubMed]

113. Bera, A.; Herbert, S.; Jakob, A.; Vollmer, W.; Götz, F. Why are pathogenic staphylococci so lysozyme resistant? The peptidoglycan $O$-acetyltransferase OatA is the major determinant for lysozyme resistance of Staphylococcus aureus. Mol. Microbiol. 2005, 55, 778-787. [CrossRef] [PubMed]

114. Vu, C.H.; Kolata, J.; Stentzel, S.; Beyer, A.; Gesell Salazar, M.; Steil, L.; Pané-Farré, J.; Rühmling, V.; Engelmann, S.; Götz, F.; et al. Adaptive immune response to lipoproteins of Staphylococcus aureus in healthy subjects. Proteomics 2016, 16, 2667-2677. [CrossRef] [PubMed]

115. Giese, B.; Glowinski, F.; Paprotka, K.; Dittmann, S.; Steiner, T.; Sinha, B.; Fraunholz, M.J. Expression of $\delta$-toxin by Staphylococcus aureus mediates escape from phago-endosomes of human epithelial and endothelial cells in the presence of $\beta$-toxin. Cell. Microbiol. 2011, 13, 316-329. [CrossRef] [PubMed]

116. Grosz, M.; Kolter, J.; Paprotka, K.; Winkler, A.-C.; Schäfer, D.; Chatterjee, S.S.; Geiger, T.; Wolz, C.; Ohlsen, K.; Otto, M.; et al. Cytoplasmic replication of Staphylococcus aureus upon phagosomal escape triggered by phenol-soluble modulin $\alpha$. Cell. Microbiol. 2014, 16, 451-465. [CrossRef] [PubMed]

117. Surewaard, B.G.J.; de Haas, C.J.C.; Vervoort, F.; Rigby, K.M.; DeLeo, F.R.; Otto, M.; van Strijp, J.A.G.; Nijland, R. Staphylococcal alpha-phenol soluble modulins contribute to neutrophil lysis after phagocytosis. Cell. Microbiol. 2013, 15, 1427-1437. [CrossRef] [PubMed]

118. Armbruster, N.S.; Richardson, J.R.; Schreiner, J.; Klenk, J.; Günter, M.; Autenrieth, S.E. Staphylococcus aureus PSM peptides induce tolerogenic dendritic cells upon treatment with ligands of extracellular and intracellular TLRs. Int. J. Med. Microbiol. 2016, 306, 666-674. [CrossRef] [PubMed]

119. Armbruster, N.S.; Richardson, J.R.; Schreiner, J.; Klenk, J.; Günter, M.; Kretschmer, D.; Pöschel, S.; Schenke-Layland, K.; Kalbacher, H.; Clark, K.; et al. PSM Peptides of Staphylococcus aureus Activate the p38-CREB Pathway in Dendritic Cells, Thereby Modulating Cytokine Production and T Cell Priming. J. Immunol. 2016, 196, 1284-1292. [CrossRef] [PubMed]

120. Deplanche, M.; Alekseeva, L.; Semenovskaya, K.; Fu, C.-L.; Dessauge, F.; Finot, L.; Petzl, W.; Zerbe, H.; Le Loir, Y.; Rainard, P.; et al. Staphylococcus aureus Phenol-Soluble Modulins Impair Interleukin Expression in Bovine Mammary Epithelial Cells. Infect. Immun. 2016, 84, 1682-1692. [CrossRef] [PubMed]

121. Dey, S.; Bishayi, B. Killing of Staphylococcus aureus in murine macrophages by chloroquine used alone and in combination with ciprofloxacin or azithromycin. J. Inflamm. Res. 2015, 8, 29-47. [CrossRef] [PubMed] 
122. Leimer, N.; Rachmühl, C.; Palheiros Marques, M.; Bahlmann, A.S.; Furrer, A.; Eichenseher, F.; Seidl, K.; Matt, U.; Loessner, M.J.; Schuepbach, R.A.; et al. Nonstable Staphylococcus aureus Small-Colony Variants Are Induced by Low $\mathrm{pH}$ and Sensitized to Antimicrobial Therapy by Phagolysosomal Alkalinization. J. Infect. Dis. 2016, 213, 305-313. [CrossRef] [PubMed]

123. Neumann, Y.; Bruns, S.A.; Rohde, M.; Prajsnar, T.K.; Foster, S.J.; Schmitz, I. Intracellular Staphylococcus aureus eludes selective autophagy by activating a host cell kinase. Autophagy 2016, 12, 2069-2084. [CrossRef] [PubMed]

124. Maurer, K.; Reyes-Robles, T.; Alonzo, F.; Durbin, J.; Torres, V.J.; Cadwell, K. Autophagy mediates tolerance to Staphylococcus aureus alpha-toxin. Cell Host Microbe 2015, 17, 429-440. [CrossRef] [PubMed]

125. Mestre, M.B.; Fader, C.M.; Sola, C.; Colombo, M.I. $\alpha$-hemolysin is required for the activation of the autophagic pathway in Staphylococcus aureus infected cells. Autophagy 2010, 6, 110-125. [CrossRef] [PubMed]

126. Korea, C.G.; Balsamo, G.; Pezzicoli, A.; Merakou, C.; Tavarini, S.; Bagnoli, F.; Serruto, D.; Unnikrishnan, M. Staphylococcal Esx proteins modulate apoptosis and release of intracellular Staphylococcus aureus during infection in epithelial cells. Infect. Immun. 2014, 82, 4144-4153. [CrossRef] [PubMed]

127. Cruciani, M.; Etna, M.P.; Camilli, R.; Giacomini, E.; Percario, Z.A.; Severa, M.; Sandini, S.; Rizzo, F.; Brandi, V.; Balsamo, G.; et al. Staphylococcus aureus Esx Factors Control Human Dendritic Cell Functions Conditioning Th1/Th17 Response. Front. Cell. Infect. Microbiol. 2017, 7, 330. [CrossRef] [PubMed]

128. Koymans, K.J.; Vrieling, M.; Gorham, R.D.; van Strijp, J.A.G. Staphylococcal Immune Evasion Proteins: Structure, Function, and Host Adaptation. Curr. Top. Microbiol. Immunol. 2017, 409, 441-489. [CrossRef] [PubMed]

129. Argudín, M.Á.; Mendoza, M.C.; Rodicio, M.R. Food poisoning and Staphylococcus aureus enterotoxins. Toxins 2010, 2, 1751-1773. [CrossRef] [PubMed]

130. Grumann, D.; Nübel, U.; Bröker, B.M. Staphylococcus aureus toxins-Their functions and genetics. Infect. Genet. Evol. 2014, 21, 583-592. [CrossRef] [PubMed]

131. Llewelyn, M.; Cohen, J. Superantigens: Microbial agents that corrupt immunity. Lancet Infect. Dis. 2002, 2, 156-162. [CrossRef]

132. Sollid, J.U.E.; Furberg, A.S.; Hanssen, A.M.; Johannessen, M. Staphylococcus aureus: Determinants of human carriage. Infect. Genet. Evol. 2014, 21, 531-541. [CrossRef] [PubMed]

133. Frazee, B.W. Severe methicillin-resistant Staphylococcus aureus community-acquired pneumonia associated with influenza-Louisiana and Georgia, December 2006-January 2007. MMWR Morb. Mortal. Wkly. Rep. 2007, 56, 325-329.

134. Barnes, P.J. Intrinsic asthma: Not so different from allergic asthma but driven by superantigens? Clin. Exp. Allergy 2009, 39, 1145-1151. [CrossRef] [PubMed]

135. Bachert, C.; Zhang, N. Chronic rhinosinusitis and asthma: Novel understanding of the role of IgE 'above atopy'. J. Int. Med. 2012, 272, 133-143. [CrossRef] [PubMed]

136. Davis, M.F.; Peng, R.D.; McCormack, M.C.; Matsui, E.C. Staphylococcus aureus colonization is associated with wheeze and asthma among US children and young adults. J. Allergy Clin. Immunol. 2015, 135, 811-813.e5. [CrossRef] [PubMed]

137. Van Zele, T.; Gevaert, P.; Watelet, J.-B.; Claeys, G.; Holtappels, G.; Claeys, C.; van Cauwenberge, P.; Bachert, C. Staphylococcus aureus colonization and IgE antibody formation to enterotoxins is increased in nasal polyposis. J. Allergy Clin. Immunol. 2004, 114, 981-983. [CrossRef] [PubMed]

138. Bachert, C.; van Steen, K.; Zhang, N.; Holtappels, G.; Cattaert, T.; Maus, B.; Buhl, R.; Taube, C.; Korn, S.; Kowalski, M.; et al. Specific IgE against Staphylococcus aureus enterotoxins: An independent risk factor for asthma. J. Allergy Clin. Immunol. 2012, 130, 376-381.e8. [CrossRef] [PubMed]

139. Stentzel, S.; Teufelberger, A.; Nordengrün, M.; Kolata, J.; Schmidt, F.; van Crombruggen, K.; Michalik, S.; Kumpfmüller, J.; Tischer, S.; Schweder, T.; et al. Staphylococcal serine protease-like proteins are pacemakers of allergic airway reactions to Staphylococcus aureus. J. Allergy Clin. Immunol. 2017, 139, 492-500.e8. [CrossRef] [PubMed]

140. Kapsenberg, M.L. Dendritic-cell control of pathogen-driven T-cell polarization. Nat. Rev. Immunol. 2003, 3, 984-993. [CrossRef] [PubMed]

141. Condon, T.V.; Sawyer, R.T.; Fenton, M.J.; Riches, D.W.H. Lung dendritic cells at the innate-adaptive immune interface. J. Leukoc. Biol. 2011, 90, 883-895. [CrossRef] [PubMed] 
142. Jin, J.-O.; Zhang, W.; Du, J.-Y.; Yu, Q. BDCA1-positive dendritic cells (DCs) represent a unique human myeloid DC subset that induces innate and adaptive immune responses to Staphylococcus aureus Infection. Infect. Immun. 2014, 82, 4466-4476. [CrossRef] [PubMed]

143. Ziegler, C.; Goldmann, O.; Hobeika, E.; Geffers, R.; Peters, G.; Medina, E. The dynamics of T cells during persistent Staphylococcus aureus infection: From antigen-reactivity to in vivo anergy. EMBO Mol. Med. 2011, 3, 652-666. [CrossRef] [PubMed]

144. Holtfreter, S.; Kolata, J.; Stentzel, S.; Bauerfeind, S.; Schmidt, F.; Sundaramoorthy, N.; Bröker, B.M. Omics Approaches for the Study of Adaptive Immunity to Staphylococcus aureus and the Selection of Vaccine Candidates. Proteomes 2016, 4, 11. [CrossRef] [PubMed]

145. Davis, M.F.; Ludwig, S.; Brigham, E.P.; McCormack, M.C.; Matsui, E.C. Effect of home exposure to Staphylococcus aureus on asthma in adolescents. J. Allergy Clin. Immunol. 2018, 141, 402-405.e10. [CrossRef] [PubMed]

146. Robinson, D.; Hamid, Q.; Bentley, A.; Ying, S.; Kay, A.B.; Durham, S.R. Activation of CD4+ T cells, increased TH2-type cytokine mRNA expression, and eosinophil recruitment in bronchoalveolar lavage after allergen inhalation challenge in patients with atopic asthma. J. Allergy Clin. Immunol. 1993, 92, 313-324. [CrossRef]

147. Romagnani, S. The role of lymphocytes in allergic disease. J. Allergy Clin. Immunol. 2000, 105, 399-408. [CrossRef] [PubMed]

148. Lambrecht, B.N.; Salomon, B.; Klatzmann, D.; Pauwels, R.A. Dendritic cells are required for the development of chronic eosinophilic airway inflammation in response to inhaled antigen in sensitized mice. J. Immunol. 1998, 160, 4090-4097. [PubMed]

149. Andreas, N.; Riemann, M.; Castro, C.N.; Groth, M.; Koliesnik, I.; Engelmann, C.; Sparwasser, T.; Kamradt, T.; Haenold, R.; Weih, F. A new RelB-dependent CD117+ CD172a+ murine DC subset preferentially induces Th2 differentiation and supports airway hyperresponses in vivo. Eur. J. Immunol. 2018, 48, 923-936. [CrossRef] [PubMed]

150. Georas, S.N.; Rezaee, F. Epithelial barrier function: At the front line of asthma immunology and allergic airway inflammation. J. Allergy Clin. Immunol. 2014, 134, 509-520. [CrossRef] [PubMed]

151. Berube, B.J.; Bubeck Wardenburg, J. Staphylococcus aureus $\alpha$-Toxin: Nearly a Century of Intrigue. Toxins 2013, 5, 1140-1166. [CrossRef] [PubMed]

152. Wilke, G.A.; Bubeck Wardenburg, J. Role of a disintegrin and metalloprotease 10 in Staphylococcus aureus alpha-hemolysin-mediated cellular injury. Proc. Natl. Acad. Sci. USA 2010, 107, 13473-13478. [CrossRef] [PubMed]

153. Damle, S.R.; Martin, R.K.; Cockburn, C.L.; Lownik, J.C.; Carlyon, J.A.; Smith, A.D.; Conrad, D.H. ADAM10 and Notch1 on murine dendritic cells control the development of type 2 immunity and IgE production. Allergy 2018, 73, 125-136. [CrossRef] [PubMed]

154. Breuer, K.; Wittmann, M.; Kempe, K.; Kapp, A.; Mai, U.; Dittrich-Breiholz, O.; Kracht, M.; Mrabet-Dahbi, S.; Werfel, T. Alpha-toxin is produced by skin colonizing Staphylococcus aureus and induces a T helper type 1 response in atopic dermatitis. Clin. Exp. Allergy 2005, 35, 1088-1095. [CrossRef] [PubMed]

155. Niebuhr, M.; Gathmann, M.; Scharonow, H.; Mamerow, D.; Mommert, S.; Balaji, H.; Werfel, T. Staphylococcal alpha-toxin is a strong inducer of interleukin-17 in humans. Infect. Immun. 2011, 79, 1615-1622. [CrossRef] [PubMed]

156. Frank, K.M.; Zhou, T.; Moreno-Vinasco, L.; Hollett, B.; Garcia, J.G.N.; Bubeck Wardenburg, J. Host response signature to Staphylococcus aureus alpha-hemolysin implicates pulmonary Th17 response. Infect. Immun. 2012, 80, 3161-3169. [CrossRef] [PubMed]

157. Inoshima, I.; Inoshima, N.; Wilke, G.A.; Powers, M.E.; Frank, K.M.; Wang, Y.; Bubeck Wardenburg, J. A Staphylococcus aureus pore-forming toxin subverts the activity of ADAM10 to cause lethal infection in mice. Nat. Med. 2011, 17, 1310-1314. [CrossRef] [PubMed]

158. Ezekwe, E.A.D.; Weng, C.; Duncan, J.A. ADAM10 Cell Surface Expression but Not Activity Is Critical for Staphylococcus aureus $\alpha$-Hemolysin-Mediated Activation of the NLRP3 Inflammasome in Human Monocytes. Toxins 2016, 8, 95. [CrossRef] [PubMed]

159. Hildebrandt, J.-P. Pore-forming virulence factors of Staphylococcus aureus destabilize epithelial barriers-effects of alpha-toxin in the early phases of airway infection. AIMS Microbiol. 2015, 1, 11-36. [CrossRef]

160. Giersing, B.K.; Dastgheyb, S.S.; Modjarrad, K.; Moorthy, V. Status of vaccine research and development of vaccines for Staphylococcus aureus. Vaccine 2016, 34, 2962-2966. [CrossRef] [PubMed] 
161. Bernstein, J.M.; Allen, C.; Rich, G.; Dryja, D.; Bina, P.; Reiser, R.; Ballow, M.; Wilding, G.E. Further observations on the role of Staphylococcus aureus exotoxins and IgE in the pathogenesis of nasal polyposis. Laryngoscope 2011, 121, 647-655. [CrossRef] [PubMed]

162. Sørensen, M.; Klingenberg, C.; Wickman, M.; Sollid, J.U.E.; Furberg, A.-S.; Bachert, C.; Bousquet, J. Staphylococcus aureus enterotoxin sensitization is associated with allergic poly-sensitization and allergic multimorbidity in adolescents. Allergy 2017, 72, 1548-1555. [CrossRef] [PubMed]

163. Bacher, P.; Heinrich, F.; Stervbo, U.; Nienen, M.; Vahldieck, M.; Iwert, C.; Vogt, K.; Kollet, J.; Babel, N.; Sawitzki, B.; et al. Regulatory T Cell Specificity Directs Tolerance versus Allergy against Aeroantigens in Humans. Cell 2016, 167, 1067-1078. [CrossRef] [PubMed]

(C) 2018 by the authors. Licensee MDPI, Basel, Switzerland. This article is an open access article distributed under the terms and conditions of the Creative Commons Attribution (CC BY) license (http:/ / creativecommons.org/licenses/by/4.0/). 